\title{
Reconnaissance of Voices: The Narrative Voices in a Short Story and a Prose Poem
}

\section{S. Rema Devi}

\begin{abstract}
A story reaches the readers through the voice of the narrator. Either be it a piece of literature, a movie or a play, the techniques a narrator adopts plays a crucial role in driving home the narrated part in the right sense. The reader should be able to feel the same as the author, provided the author uses the right tone of the narration. The narration may be from different perspectives. The narration may be in the first-person or the third person; the tense may be either present or past; the usage of foundational devices like similes and metaphors may be used; with a goal of attaining fulfilment in telling a story, the narrator may shift the responsibility of imagination from his or her own shoulders to the shoulders of the readers, so that the readers visualize the story with hues of their own imagination, immersed in scenes of their flair. To an extent, dialogues also play a vital role in allowing the reader to experience the words of the characters in the storyline. The present paper analyses two pieces of literature - a short story and a prose poem. The common thread that connects both the literary pieces is that they project images of a mother-daughter relationship. The paper compares Alice Munro's “Voices” and Jamaica Kincaid's “Girl”.
\end{abstract}

Keywords: Comparison, Alice Munro, “Voices”, Jamaica Kincaid, "Girl"

\section{INTRODUCTION}

A story reaches the readers through the voice of the narrator. Either be it a piece of literature, a movie or a play, the techniques a narrator adopts plays a crucial role in driving home the narrated part in the right sense. The reader should be able to feel the same as the author, provided the author uses the right tone of the narration. The narration may be from different perspectives. The narration may be in the first -person or the third person; the tense may be either present or past; the usage of foundational devices like similes and metaphors may be used; with a goal of attaining fulfilment in telling a story, the narrator may shift the responsibility of imagination from his or her own shoulders to the shoulders of the readers, so that the readers visualize the story with hues of their own imagination, immersed in scenes of their flair. To an extent, dialogues also play a vital role in allowing the reader to experience the words of the characters in the storyline.

\section{OBJECTIVE OF THE STUDY}

The objective of the present paper is to analyze two pieces of literature - a short story and a prose poem. The

Revised Manuscript Received on December 20, 2019.

* Correspondence Author

Rema Devi S.*, Associate Professor \& Head, Department of English, Kalasalingam Academy of Research and Education, Krishnankoil, Virudhunagar District, Tamil Nadu, India. Email: remagopu@ gmail.com common thread that connects both the literary pieces is that they project images of a mother-daughter relationship. The paper compares Alice Munro's "Voices" and Jamaica Kincaid's "Girl". The study also emphasizes the narrative techniques of these works.

\section{Methodology}

Among the other methods of analyzing or examining the texts, narrative is the most difficult one to define; across many disciplines, no common understanding exists. This is not surprising as the philosophical assumptions of narrative theory strike deeply at fundamental philosophical problems in science, especially at the relationship between the empirical and the symbolic, between signs and their referents. The methodology adopted for this study is to analyze the narrative techniques of Alice Munro's "Voices" and Jamaica Kincaid's "Girl". Notably, the author of the present study examines the texts by using the narrative devices such as similes and metaphors.

\section{Narrative Analysis of Alice Munro's Voices}

Alice Munro, the popular Canadian short story writer and Nobel recipient for literature in 2013, has revolutionized the architecture of short stories. She presents her stories in a timeline which swings to and fro. She always has succeeded in exploring the human complexities. Something remarkable about the stories of Munro is that they are always in simple and uncomplicated prose style. Though a recipient of many literary accolades, her stories are those with a strong regional focus and based on small-town settings. Her stories are deep rooted in customs and traditions. Her short story collections include Dance of the Happy Shades (1968), Lives of Girls and Women (1971), Something I've Been Meaning to Tell You (1974), Who Do You Think You Are? (1978), The Moons of Jupiter (1982), The Progress of Love (1986), Friend of My Youth (1990), Open Secrets (1994), The Love of a Good Woman (1998), Runaway (2004), The View from Castle Rock (2006), Too Much Happiness (2009) and Dear Life (2012).

The story "Voices" is from the collection Dear Life. The story ensnares a dance party in the neighbourhood, during the wartime. The narrator recollects her mother's love for dance. Hailing from a farmhouse, the mother of the narrator loves dances. When she is married and is with three kids, she loves to go for dances but finds herself in an "odd situation", because she is neither fully in the town nor fully in the country. Though she has risen to the level of a school teacher, she is not satisfied with her life because she does not receive any appreciation for her so called elevated language and manners.

The story spins around a flashback, when the 
narrator is a ten-year old lass, accompanying her mother to a dance on the same road where they dwell. The narrator knows little of the house and the family that hosts the dance. The narrator is too young to analyse the reason behind hosting a dance and the reason behind her father staying at home, taking care of the two younger kids. Consequently, it is the narrator who accompanies her mother to the dance. Dressed in their best clothes, the two head towards the house and the rest of the story is recounted by the narrator about the visuals in that little house. She comes across a woman in a better dress than her mother's, a man who dances with her, a young girl, who kept on crying and two young men in Air Force Uniforms. Later, the narrator comes to know that the lady in the nicer dress is a notorious prostitute and that has been the reason for them leaving earlier from the dance party.

The narrator's mother orders her to fetch the coats and on the way upstairs, the narrator recalls the presence of a young girl by name Peggy and the two young men comforting her. This scene and the voices of the young men remain with the narrator. She is, later, able to realize that the men had a tinge of lust for Peggy and that was the reason they were hanging around her. However, something remarkable is the voices of the men. The narrator recollects, "It was her comforters I marvelled at. How they seemed to bow down and declare themselves in front of her." [1] The voices of the men make the narrator envy Peggy. The narrator says, "I just thought of the blessing, how wonderful to get on the receiving end of it, how strangely lucky and undeserving was that Peggy." [1] The narrator, for reasons unknown, is attracted towards the soothing voices. She wonders if people could be kind and soothing to each other like this. The narrator being a keen observer of the intricate details, though seeming insignificant, the scene gets imprinted on her mind, which has a remarkable effect as the process of obtaining maturity deepens. The voices of the young men have a pervasive influence on the narrator, that she emphasizes saying, "Such kindness. That anybody could be so kind." [2]

As Burner says, the human cognition is of two types, namely the logico-scientific and the narrative. The narrative form reaches the zenith of imagination, enhancing the imaginative powers of the readers. A narrative piece has its emotional impact on the readers. This emotional appeal may be touching, humorous or ironic. The emotional appeal may have a wide bandwidth, pushing the narrator towards the path of accomplishment in kindling the same emotions in the minds of the readers. At this juncture, the stories lose their objective truth. The narrator longs for a soothing touch or words and she says, "And, for I don't know how long, I thought of them. In the cold dark of my bedroom they rocked me to sleep. I could turn them on, summon up their faces and their voices - but oh, far more, their voices were now directed to myself and not to any unnecessary third party. Their hands blessed my own skinny thighs and their voices assured me that I, too, was worthy of love.

And while they still inhabited my not yet quite erotic fantasies they were gone." [3]

Though the words of the author seem to be metanarrative, her narration is embedded in a context, which is a particular incident recalled from her memory. The narration is told subjectively from the perspective of the narrator. This is the motive that makes the readers focus on the voices of the young men and obviously the voice and tone of the narrator, rather than the incident itself. The narration kindles the sense of experience in the readers. Though the time and the plot are retrospectively aligned and the events and actions are modified with a design to linger in the minds of the readers, the voice of the narrator replaces the retrospective design.

Though the story line of the narrator sounds linear, it houses multiple and complex details like the appearance of the prostitute, the condition of the house, the status of the family which hosts the dance, the refreshment served on the table, the minute details that are furnished regarding the environment of the incident, etc. The main forte of the narrative is the inherent subjectivity. Irreducibly, the narration is subjective and perspectival. Perhaps, the earlier sufferings or the later sufferings in life would have made the narrator recall the soothing voices of the young men, which she thinks she deserves, unlike Peggy. The voices of the men still linger with the softness and kindness in the minds of the readers because the narrator drives home the same feel as that of her.

\section{NARRATIVE ANALYSIS OF JAMAICA KINCAID'S GIRL}

Jamaica Kincaid, the Antiguan-American novelist and essayist, is well known for interweaving autobiographical elements. The themes of colonialism, gender issues and racism have found priority in her works. She has also focused on mother-daughter relationships, British and American imperialism, power and adolescence. She has emphasized on political and social concerns in her select works. The culturally specific and experimental writings of Kincaid are pieces of keen observation and abruptness. Her popular novels are Annie John (1985), Lucy (1990), The Autobiography of My Mother (1996), Mr Potter (2002) and See Now Then (2013). Her uncollected fiction include "Ovando" (1989), "The Finishing Line" (1990), "Biography of a Dress" (1992), "Song of Roland" (1993) and "Xuela" (1994). At the Bottom of the River (1983) is her short story collection. Apart from this, she has an array of non-fiction and uncollected fiction, to her credit.

The selected prose poem "Girl" is from At the Bottom of the River. The prose poem is narrated by an unnamed narrator. The readers can identify that the narrator is the mother, instructing her daughter, what and how things have to be done. The significance of the voice lies in the fact that the mother's intends in moulding her daughter, with a touch of orthodoxy. Since the girl's voice is heard only twice, it means that her voice is suppressed and is taught how to adhere to tradition. The girl is exposed only to rules of domesticity and not given any exposure to the external world of education or employment. The voice also exhibits a tinch of control of the mother on her daughter. At this juncture, arises the question of the daughter's identity.

The daughter's voice is heard only twice and the mother shows no patience in answering the daughter's words first. The second response of the daughter is reciprocated with a tone of disappointment which states if she would grow up only to be a woman shunned away by the baker.

Perhaps, the mother
thinks that all her
Published By:
Blue Eyes Intelligence Engineering
\& Sciences Publication


instructions would fall on deaf ears. The subservience can be attributed to the gender of her child. Being a woman, the mother realizes the constraints on the gender. She will not be allowed choices; moreover, she will have to be subservient to her man. The two feeble responses from the daughter show that she is ready to accept all instructions by her mother.

The main strength of the narrative is its intrinsic subjectivity. The situation is perspectival. The perspective sounds to be that of the disadvantaged gender. Being a frequent theme in classical literature, the mother voices the struggle of every woman in domesticity. The inherent subjectivity is not proportional to the challenge of the narrative. The line of demarcation is conspicuous with the inconsistency and the emotionality of the stories. As Gabriel avers, "It is the researcher's task not merely to celebrate the story or the narrative but to seek to use it as a vehicle for accessing deeper truths than the truths, half-truths and fictions of undigested personal experience." [4] In the select prose poem, the narration is the vehicle to assess the individuality of the daughter and the responsibilities placed on her shoulders. It is the narration that flavours the richness and the voice of the prose poem.

\section{CONCLUSION}

Thus the present paper underpins the narrative approach in the select short story and the prose poem. The paper justifies how the voices of the narrators reconnoitre - the voice of the young air men and the voice of the mother in the short story "Voices" and the prose poem "Girl”, respectively.

\section{REFERENCES}

1. Munro, Alice. Dear Life. New York: Vintage Books, 2012. Print

2. Kincaid, Jamaica. At the Bottom of the River. New York: Farrar, Straus and Giroux, 1983. Print.

3. Aristotle. Poetics. Translated by Malcolm Heath. London Penguin, 1996:540.

4. Bruner J. Actual minds, possible words. Cambridge: Harvard University Press, 1986.

5. Gabriel Y. The voice of experience and the voice of the expert - can they speak to each other? In: Hurwitz B, Greenhalgh T, Skultans V, eds. Narrative research in health and illness. London: BMJ Publications, 2004.

\section{AUTHOR'S PROFILE}

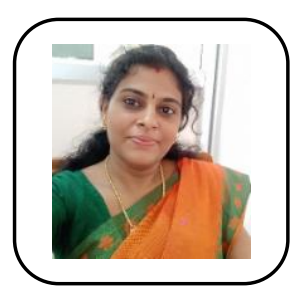

Dr S. Rema Devi is an academician. She has completed her post-graduation and doctorate in English literature from the Manonmaniam Sundaranar University in Tamil Nadu, India. She has authored two books, published thirteen papers in various journals and five papers in conference proceedings. She is in the editorial panel of three peer-reviewed journals. She has around fifteen years of experience in the field of teaching English language and literature. She is a member of the Lavender Literary Club. She has received various awards. She, at present, heads the Department of English at Kalasalingam Academy of Research and Education, Krishnankoil, Virudhunagar District, Tamil Nadu, India. 